\title{
Two new orthothecids from the Cambrian of the Barrandian area (Hyolitha, Skryje-Týřovice Basin, Czech Republic)
}

\author{
MARTIN VALENT, OLDŘICH FATKA, MICHAL SZABAD, VÁCLAV MICKA \& 'LADISLAV MAREK
}

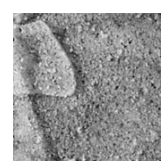

\begin{abstract}
Two orthothecid hyoliths Probactrotheca briketa new genus and new species and Circotheca smetanai new species are described from the Middle Cambrian Buchava Formation of the Skryje-Týřovice Basin in the Czech Republic. The new forms are based on about twenty well-preserved external and internal moulds of opercula and conchs. The stratigraphic range and geographic distributions for both taxa are well known. - Key words: hyoliths, orthothecids, Circotheca, Probactrotheca, Cambrian Series 3, Skryje-Týřovice Basin, Teplá-Barrandian region, Czech Republic.
\end{abstract}

VAlENT, M., FATKA, O., SZABAD, M., MiCKA, V. \& MAREK, L. 2012. Two new orthothecids from the Cambrian of the Barrandian area (Hyolitha, Skryje-Týřovice Basin, Czech Republic). Bulletin of Geosciences 87(2), 241-248 (5 figures). Czech Geological Survey, Prague. ISSN 1214-1119. Manuscript received August 31, 2011; accepted in revised form November 11, 2011; published online December 14, 2011; issued March 30, 2012.

\begin{abstract}
Martin Valent, National Museum, Department of Palaeontology, Václavské nám. 68, 11579 Prague 1, Czech Republic; martin_valent@nm.cz・Oldřich Fatka, Charles University, Institute of Geology and Palaeontology, Albertov 6, 12843 Prague 2, Czech Republic; fatka@natur.cuni.cz•Michal Szabad, Obráncủ míru 75, 26102 Př́bram VII, Czech Republic •Václav Micka, Śatrova 662, 14200 Praha 4 - Kamýk, Czech Republic • Ladislav Marek, Institute of Geology, v.v.i., Academy of Sciences of the Czech Republic, Rozvojová 269, 16502 Praha 6-Lysolaje, Czech Republic (deceased)
\end{abstract}

Cambrian sediments of the Teplá-Barrandian region contain a common and well diversified invertebrate fauna, including several types of tubular and conical fossils. Microscopic to submicroscopic nonbiomineralized tubes were described as Rhabdotubus robustus Maletz et al., 2005. The rare occurrence of Vermes indet. and Selkirkia Walcott, 1911 was reported by Fatka et al. (2004, p. 379) and Mergl \& Kordule (2008), respectively; Fatka et al. (in press) described two species of the genus Sphenothallus Hall, 1847.

Sixteen usually gregarious and locally very common hyolith species have been collected from different stratigraphical levels of the Jince Formation in the PříbramJince Basin (Fatka et al. 2004; Valent 2004, 2006; Valent et al. 2009) and the Skryje Member of the Buchava Formation in the Skryje-Týřovice Basin (Marek 1983a, Fatka 1990, Valent 2006, Valent et al. 2011a, b).

The first Cambrian hyolithids from the Teplá-Barrandian region were established by Barrande (1867) and Novák (1891). New taxa, as well as revisions of selected earlier forms, were published in a series of short papers by Marek (1972, 1975, 1980, 1981) and Valent et al. (2009, 2011a, b). Recently, Martí Mus \& Bergström (2005) revised the morphology of the genus Maxilites Marek, 1972. All so far described taxa are classified within the Order
Hyolithida Sysoev, 1957. However, knowledge concerning forms of the Order Orthothecida Marek, 1966 is much more restricted, being briefly mentioned in three papers only: Marek (1975) cited the presence of an orthothecid in the Skryje-Týřovice Basin; Marek (1976, fig. 5B) published a reconstruction of an undescribed species of Circotheca, this species is described herein as Circotheca smetanai sp. nov.; Fatka et al. (2004) reported the stratigraphic distribution of Orthotheca sp. and $O$. sp. B within the Jince Formation of the Příbram-Jince Basin. Valent et al. (in press) formally described five new species known already to Marek as the orthothecids Gracilitheca mirabilis Valent et al., G. triangularis Valent et al., Gracilitheca sp., Nephrotheca betula Valent et al. and Nephrotheca sp.

This contribution describes two additional forms of orthothecids based on material from several classical localities in the Skryje Member of the Buchava Formation in the Skryje-Týřovice Basin. Both new taxa, together with eight other hyolith species, were previously distinguished, but invalidly described, by Marek (1983a) in an unpublished report prepared for the Academy of Science of the Czech Republic. In his manuscript, Marek described both taxa in detail but he did not unambiguously designate or illustrate any type specimens and left no photographs. This paper is dedicated to the fond memory of Dr. Ladislav Marek. 


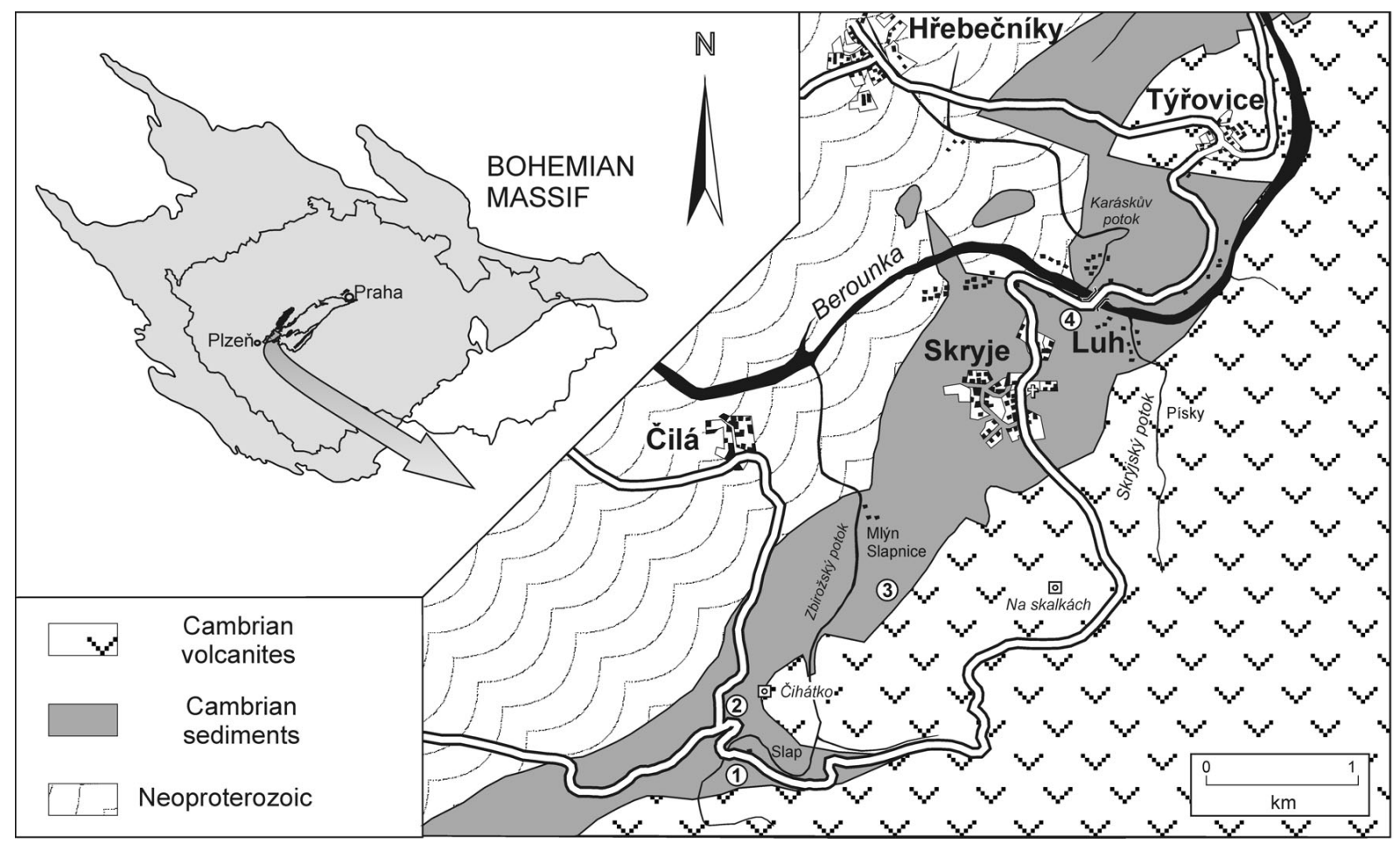

Figure 1. Simplified sketch map showing the location of fossil sites in the Middle Cambrian Buchava Formation within the Skryje-Týřovice Basin, Central Bohemia. (Geology modified from Mašek et al. 1997.) 1 - Buchava locality, 2 - rocks near Zbiroh stream opposite the Buchava quarry, 3 - Dlouhá hora Hill and 4 - Skryje-Luh locality (southern slope above the Skryje stream).

\section{Systematic palaeontology}

Class Hyolitha Marek, 1963

Order Orthothecida Marek, 1966

Family Circothecidae Missarzhevskij, 1969

\section{Genus Circotheca Sysoev, 1958 emend. Berg-Madsen \& Malinky, 1999}

Type species. - Hyolithus (Orthotheca) stylus Holm, 1893; Cambrian Series 3, Sweden, Paradoxides forchhammeri Regional Stage, Solenopleura brachymetopa and Lejopyge laevigata zones.

Discussion. - Berg-Madsen \& Malinky (1999, pp. 873 to 875 ) selected a lectotype for the type species and figured the internal and external surfaces of both opercula and conchs; they also provided a new description of the type species, including detailed information on its stratigraphic range. Using the internal morphology of the operculum as the most important diagnostic feature, the concept of Circotheca was restricted by Berg-Madsen \& Malinky (1999). On account of the presence of bent growth lines, corroborating the non planar aperture, they did not accept the emendation proposed by Missarzhevskiy (1969).
Occurrence. - Middle Cambrian to Ordovician. Specimens assigned to this genus are reported from Baltica (Sweden), Laurentia (U.S.A., Mexico), Siberia, and different European and Asian peri-Gondwanan regions (Bohemia, France, England, India and China), respectively.

Species. - At least 38 species have been included in this genus (see Berg-Madsen \& Malinky 1999), but the true number of species recognized in the literature is impossible to enumerate.

\section{Circotheca smetanai sp. nov.}

Figures 2A-D, G, K, 3

1975 Circothecid. - Marek, p. 66.

1976 Circotheca sp. nov. - Marek, fig. 5B.

1983a Circotheca smetanai sp. n. - Marek, pp. 10-12 (MS).

Holotype. - Outer surface of operculum; L40465 (Fig. 2C, D), Buchava locality. Deposited in the collection of the National Museum, Prague, Czech Republic.

Paratypes. - Inner surface of operculum; L40469 (Fig. 2A), Biskoupky locality. External mould of conch; L40467 (Fig. 2K), Buchava locality. All specimens are deposited in 

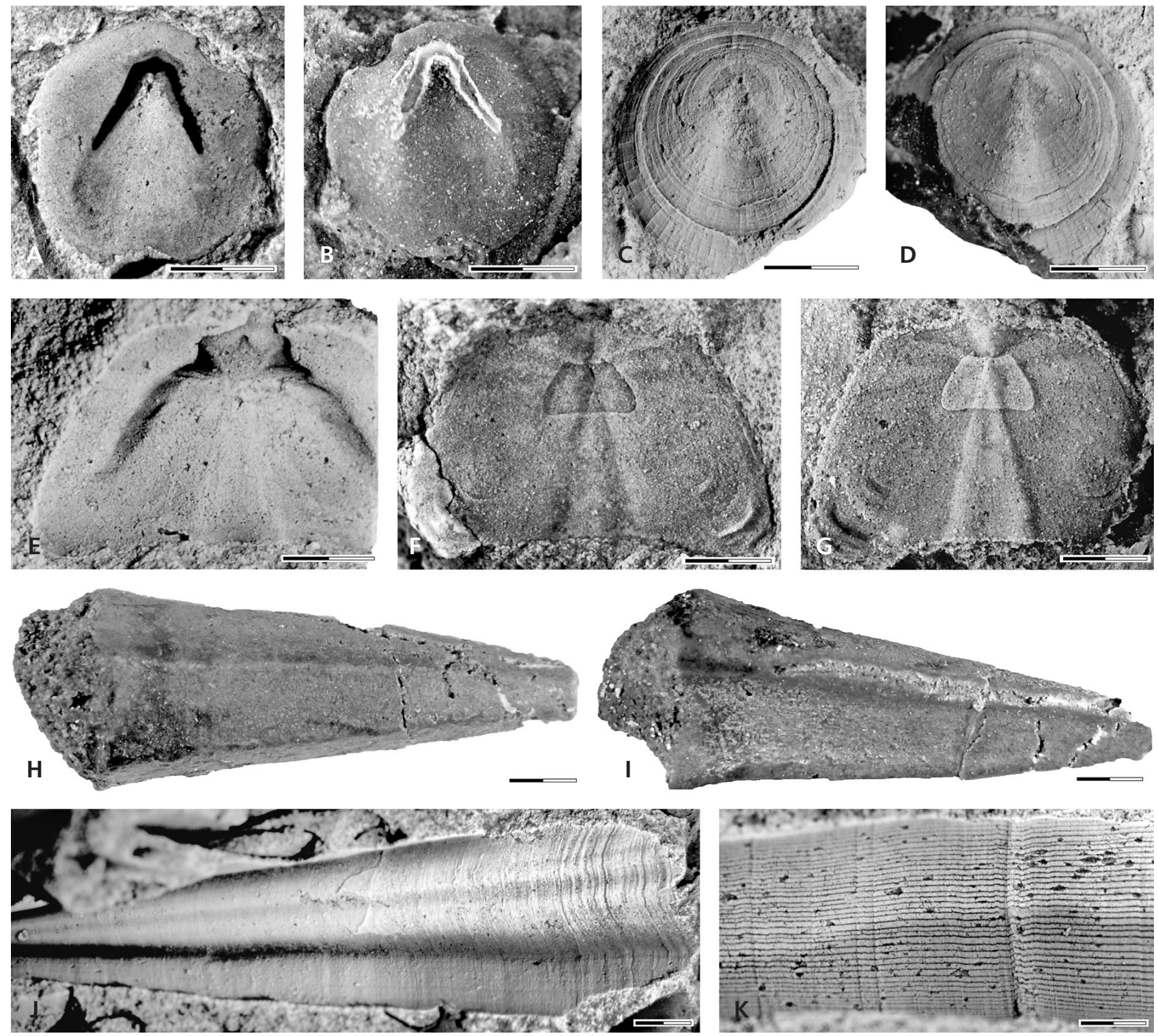

Figure 2. Circotheca smetanai sp. nov. (A-D, K) and Probactrotheca briketa gen. et sp. nov. (E-K); Middle Cambrian, Buchava Formation, Skryje Member, Paradoxides (Eccaparadoxides) pusillus Zone. Scale bar $=1 \mathrm{~mm}$. All specimens are deposited at the Palaeontological Department of the National Museum, Prague. Circotheca smetanai sp. nov. • A - inner surface of operculum, Biskoupky locality. L40469 (paratype). B - inner surface of operculum. Latex cast of L40469 (paratype). $\bullet \mathrm{C}$ - outer surface of operculum, Buchava locality. L40465 (holotype). $\bullet$ D - outer surface of operculum. Latex cast of L40465 (holotype). K - external mould of conch, Buchava locality. L40467 (paratype). Probactrotheca briketa gen. et sp. nov. • E - inner surface of operculum, Biskoupky locality. L40472 (paratype). $・$ F - outer surface of operculum, Buchava locality. L40473 (holotype). $\bullet \mathrm{G}$ - outer surface of operculum. Latex cast of L40473 (holotype). $\bullet \mathrm{H}-$ dorsal view of isolated conch, Biskoupky locality. L40470 (paratype). $\bullet$ I - ventro-lateral view of isolated conch, Biskoupky locality. L40470 (paratype). $\bullet \mathbf{J}-$ dorsal outer surface of conch, Biskoupky locality. L40572 (paratype).

the collection of the National Museum, Prague, Czech Republic.

Type horizon and locality. - Cambrian Series 3, Buchava Formation, Skryje Member, Paradoxides (Eccaparadoxides) pusillus Biozone; Skryje-Plazy locality, SkryjeTýřovice Basin, Teplá-Barrandian region, Czech Republic.
Derivation of name. - After Vojtěch Smetana, for his contribution to the understanding of the Bohemian Cambrian.

Material. - Twelve conchs and six opercula.

Diagnosis. - Circotheca with sub-circular operculum, summit of operculum displaced slightly dorsally. External surface of operculum with well developed concentric 
irregularly disposed growth-lines. Outer surface of conch bears very narrow, corrugate ribs which are T-shaped in cross-section.

Description. - Narrow orthocone conch (Fig. 3C) of sub-circular cross-section; slightly dorso-laterally curved ( $\mathrm{V}+, \mathrm{D}-)$. The angle of divergence reaches about 8 degrees. The aperture is slightly bowed from the dorsal to the ventral margin. A distinct wall surrounding the aperture is developed on internal moulds, representing a sudden tapering of the wall. Muscle scars were not ascertained. The preservation state of the internal moulds excludes any detection of apical septa.

The sculpture of the conch surface consists of very narrow and corrugating ribs (Fig. 2K). The distal ends of ribs form a T-like shape in the cross-section.

The operculum is sub-circular in outline, slightly concave in cross-section (Fig. 2A-D). The apex of the operculum situated excentrically, being slightly displaced dorsally. A narrow, flat and poorly developed depression runs ventrally from the opercular summit (Fig. 2D). The external surface sculpture consists of infrequent, irregularly disposed but clearly visible concentric growth-lines (Fig. 2C, D); regularly spaced radial ribs are well developed.

The internal surface of the operculum bears a pair of large bilobate cardinal processes (Fig. 2A, B). The prominent lobes are broadly rounded frontally and laterally; distal parts are postero-laterally elongated. The cardinal processes attain two thirds of the opercular length; their bases diverge at the angle of about 80 degrees.

Dimensions. - The maximum length of the conch reaches at least $40 \mathrm{~mm}$; width of the aperture ranges around $5 \mathrm{~mm}$.

Discussion. - Circotheca smetanai sp. nov. is the third species of the genus Circotheca in which both the conch as well as the operculum are known [the others are $C$. styla (Holm, 1893), Cambrian of Sweden and C. caperai Marek, 1983b, Ordovician of Morocco]. A restudy of Holm's (1893) material showed that the original specimen is preserved in limestone and the surface sculpture of the conch is eroded; only a small part of the conch shows bases of the wavy warped longitudinal ribs (see Berg-Madsen \& Malinky 1999 , pp. 874, 875, text-fig. 9). Only the bases of the cardinal processes, diverging at the angle of about 60 degrees, are developed on the inner surface of the operculum which Holm (1893) assigned to this species. However, the angle of divergence is markedly smaller than in C. smetanai.

Circotheca caperai Marek, 1983b ("Arenigian" of Montagne Noire, France) differs from the mentioned species with regard to the shorter bases of cardinal processes and in the sharply undulating longitudinal ribs developed on the outer surface of conch.
Occurrence. - Circotheca smetanai sp. nov. is quite a rare species in the Skryje Member (Buchava Formation) of the Skryje-Týřovice Basin. The species is known from the Biskoupky locality, Buchava locality, rocks near Zbiroh stream opposite the Buchava quarry, Dlouhá hora and Skryje-Luh localities (southern slope above the Skryje stream) (Figs 1, 5).

Remarks on stratigraphy. - The presence of C. smetanai has been established in the lower third of the Buchava Formation, near the base of the Paradoxides (Eccaparadoxides) pusillus Biozone (Fig. 5), in levels which are correlated with the upper Leonian regional Stage (Álvaro et al. 2004, fig. 5). The Leonian Stage corresponds to the $\mathrm{Pa}$ radoxides oelandicus regional Stage of Baltica (Geyer \& Shergold 2000, table 1). Until now, the oldest species of Circotheca, C. styla, has been described from the Solenopleura brachymetopa trilobite zone of south Sweden (Berg Madsen and Malinky 1999, pp. 844, 874, 875; Malinky 2009, p. 589). Specimens described and figured recently by Peel (2010) and Peel \& Ineson (2011) from the early Cambrian Sirius Passet Lagerstätte of Greenland show surface sculpture of conch and circular operculum and could belong to Circotheca.

C. smetanai thus represents the oldest described occurrence of the genus Circotheca.

\section{Family uncertained}

\section{Genus Probactrotheca gen. nov.}

Type species. - Probactrotheca briketa sp. nov.; Cambrian Series 3, Buchava Formation, Skryje Member, SkryjeTýřovice Basin, Teplá-Barrandian region, Czech Republic.

Diagnosis. - Medium sized orthocone conch with a small angle of divergence, and trapezoid cross-section. Ventral side concave; dorsal side divided longitudinally into three parts: the middle part with slightly raised rounded keel on the mould and with slightly vaulted lateral shoulders. The boundaries between these three parts are rounded, as is the junction with the ventral side. The ventral apertural margin is straight; the dorsal margin is slightly arched adapically cut out. The sculpture of the conch consists of fine growth-lines.

The flat operculum is sub-trapezoid in outline. Its inner side bears narrow broadly diverging cardinal processes with subparallel edges. The lower walls are distinct. Plicae are well developed on the outer side; the slightly convex triangulum is distinct. The sculpture of the operculum consists of fine distinct growth-lines.

Discussion. - Probactrotheca gen. nov. is reminiscent of the genera Bactrotheca Novák, 1891, Quadrotheca Sysoev, 
1958, Trapezotheca Sysoev, 1958 and Holmitheca Sysoev, 1968.

In Trapezotheca, based on the Lower Ordovician type species Hyolithus (Orthotheca) aemulus Holm, 1893, the ventral side is much less concave and the conch sculpture consists of longitudinal elements. The Lower Cambrian genus Holmitheca (type species Holmitheca obvia Sysoev, 1968) shows well rounded edges of the conch especially those, which separate middle part of the dorsal side from the lateral sides. Opercula of Trapezotheca and Holmitheca are unknown. The similar genus Quadrotheca Sysoev, 1958 emended Malinky, 2002 [type species: Hyolithes (Orthotheca) quadrangularis Holm, 1893], the only genus of the Family Quadrothecidae Malinky, 2002, differs in possessing a flat dorsum and venter. The genus Bactrotheca Novák, 1891 (type species Hyolithes teres Barrande, 1867) shows a flat venter without a broad shallow furrow and flat dorsum.

All orthothecids with a "quadrate" cross-section were traditionally classified within the family Orthothecidae Sysoev, 1958. Malinky (1987) provided the following emended diagnosis of this family: "Orthothecids with inflated, angular dorsum and slightly inflated venter, forming a subtriangular transverse outline; ornament on exterior of shell may be longitudinal, transverse, or combination of both. Unlike Fisher (1962), Malinky (1987, p. 947) proposed to exclude from this family seven genera including Bactrotheca and Quadrotheca. Consequently, Malinky (2002, p. 541) established a new family, Quadrothecidae, with only one genus Quadrotheca. In their most recent paper Malinky et al. (2009) refrained from classifying Bactrotheca within any family. Malinky (2009) changed the concept of the family Orthothecidae and included its type genus Orthotheca Novák, 1886 and six other genera. This most recent concept excludes the genera Bactrotheca and Quadrotheca from this family. In conclusion, the new genus Probactrotheca does not fall within any recognised family as they are presently diagnosed.

Species. - Monotypic genus with species Probactrotheca briketa sp. nov.

Occurrence. - Middle Cambrian, Skryje-Týřovice Basin, Bohemia.

\section{Probactrotheca briketa sp. nov.}

Figure 2E-J, 4

1983a Probactrotheca briketa sp. n. - Marek, pp. 15-17 (MS).

Holotype. - L40473 (Fig. 2F, G). Outer surface of opercu-

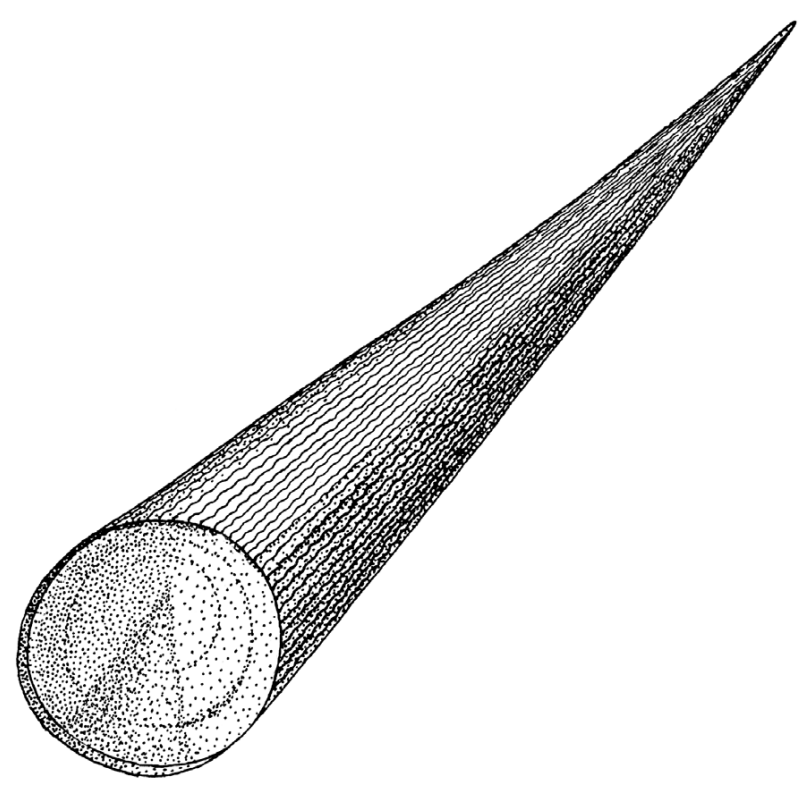

Figure 3. Circotheca smetanai sp. nov., reconstruction of conch with attached operculum. (Modified from Marek 1976.)

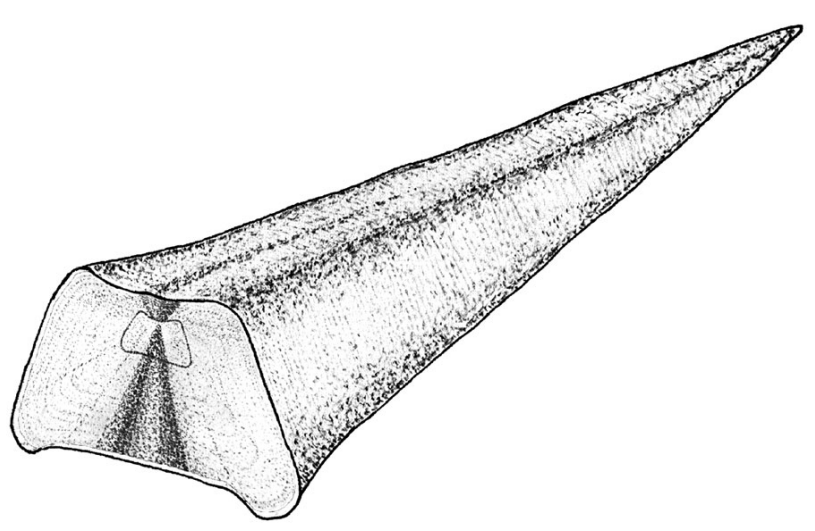

Figure 4. Probactrotheca briketa sp. nov., reconstruction of conch with attached operculum.

lum deposited in the collection of the National Museum, Prague, Czech Republic. Buchava locality.

Paratypes. - Inner surface of operculum; L40472 (Fig. 2E). Internal mould of the conch; L40470 (Fig. 2H, I). External mould of conch; L40572 (Fig. 2J). All specimens come from the Biskoupky locality and are deposited in the collection of the National Museum, Prague, Czech Republic.

Type horizon and locality. - Cambrian Series 3, Buchava Formation, Skryje Member, Paradoxides (Eccaparadoxides) pusillus Biozone; Biskoupky locality, Skryje-Týřovice Basin, Teplá-Barrandian region, Czech Republic.

Material. - In addition to the holotype and paratypes, two other incomplete moulds and five external conch imprints. 


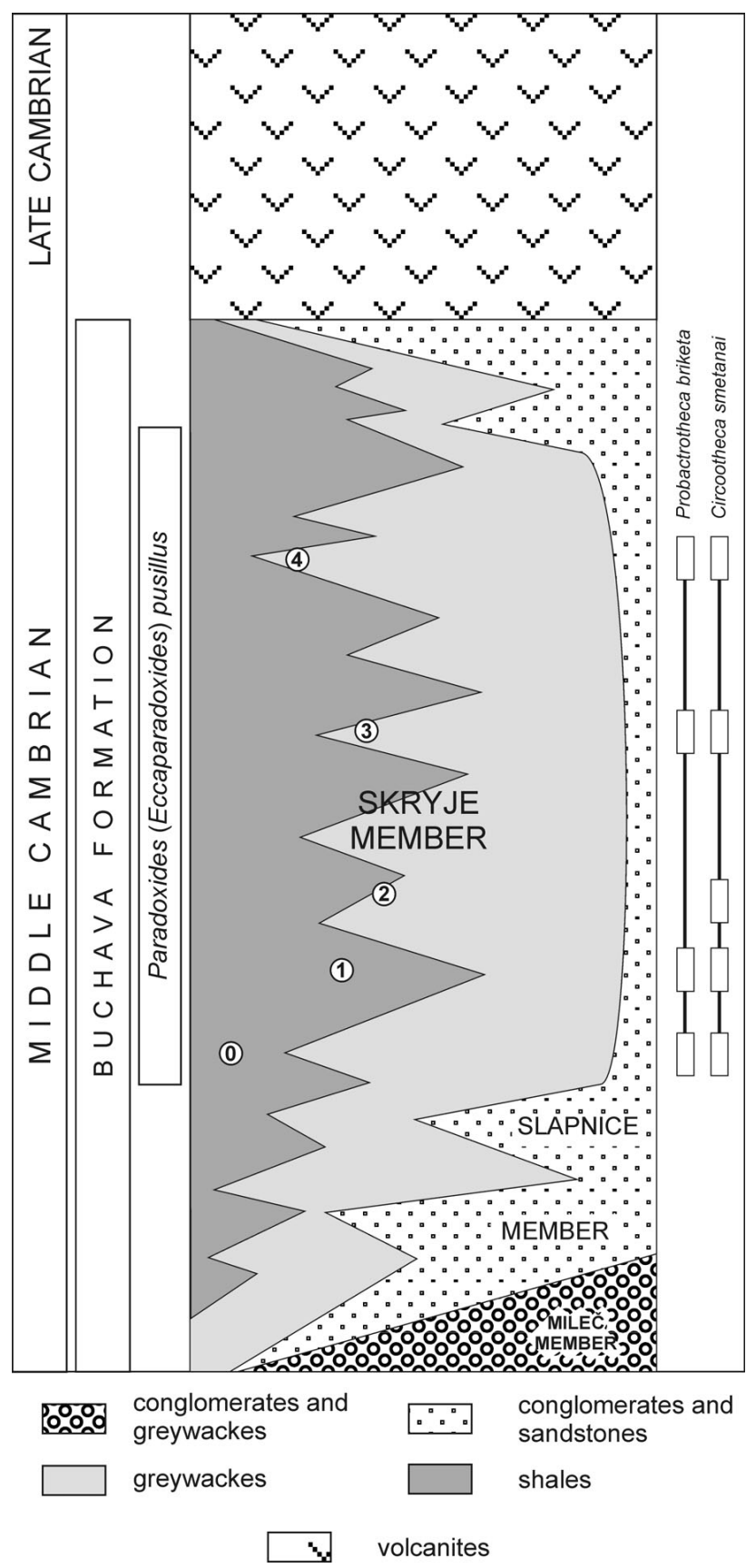

Figure 5. Stratigraphic distribution of Circotheca smetanai sp. nov. and Probactrotheca briketa gen. et sp. nov. within the Buchava Formation of the Skryje-Týřovice Basin (biostratigraphy after Fatka et al. 2011). 0-Biskoupky locality; 1 - Buchava locality; 2-rocks near Zbiroh stream opposite the Buchava quarry; 3 - Dlouhá hora Hill and 4 - Skryje-Luh locality (southern slope above the Skryje stream).

Diagnosis. - The same as for the genus.

Description. - Orthocone conch, subtrapezoidal in cross-section. The angle of divergence ranges from 10 to 12 degrees, $w / h$ index $=1.55$. The ventral side is strongly concave; the concavity is about one seventh of the height of the conch. On the dorsal surface of the conch, the slightly arched dorsal flat part carries an indistinct, broadly rounded medial keel and the almost flat lateral sides can be recognised (Fig. 4). The keel is more distinct on internal moulds. Strongly rounded edges separate the lateral sides from the ventral as well as the dorsal surfaces of the conch. The aperture is perpendicular to the conch axis. The ventral apertural margin is excavated slightly backward. Muscle scars were not found. The apical part is not preserved in any of the conchs, hence it is not known if apical septa were developed.

In the best preserved specimens, indistinct, very fine growth-lines are developed on the outer surface of the conch (Fig. 2J).

The flat operculum is sub-trapezoidal in outline (Fig. 2E-G), its ventral margin slightly arched. The cardinal processes are narrow (exsag.), broadly diverging and virtually of the same width. Their proximal ends are strongly internally curved to the inner surface of the operculum and merge with its surface. The distal ends of the cardinal processes are free. Narrow, distinct but low walls extend from about half of the length (tr.) of the cardinal processes in a shallow arch towards the anterior lateral opercular margins (Fig. 2E). Plicae are distinct and separated by a shallow furrow; their outer margins reach an angle of about 55 degrees. A small and slightly vaulted triangular area lies between the summit and the dorsal opercular margin. A thin conical projection with a diameter of $0.3 \mathrm{~mm}$ is developed in the centre of the opercular summit and is interpreted as a protooperculum. This clearly visible shield, which rises above the remainder of the operculum, represents an early ontogenetic stage. A distinctly separated, centrally located sub-trapezoidal shield representing the earliest ontogenetic stages rises above the rest of operculum. The shield differs in shape from the adult specimen's opercula in its straight anterior margin and in sharper corners.

The outer surface of operculum is covered by fine growth-lines (Fig. 2F, G).

Dimensions. - The conch of the adult specimen was at least $30 \mathrm{~mm}$ long.

Discussion. - Probactrotheca briketa sp. nov. differs from all other orthothecids of similar cross-section in the distinct ridges separating the different parts of the conch. The most similar species is the Lower Ordovician (Dapingian) Quadrotheca quadrangularis (Holm, 1893) from Sweden but the sculpture in this species consists of longitudinal riblets.

Occurrence. - Probactrotheca briketa sp. nov. is known only from the Skryje Member (Buchava Formation) of the Skryje-Týřovice Basin at the Biskoupky, Buchava, Dlouhá Hora Hill, and Skryje-Luh localities (Figs 1, 5). 


\section{Stratigraphy and palaeoecology}

Both new species have been recognized in different stratigraphical levels at several localities of the Skryje Member, Buchava Formation, within the Paradoxides (Eccaparadoxides) pusillus Biozone (Fig. 5).

Dzik (1978) and Nützel et al. (2006) documented the large size of early ontogenetic shells (= protoconchs) in several groups of early molluscs, including specimens of the Ordovician orthothecid Bactrotheca Novák, 1891. This morphological feature has been suggested as a decisive argument for the presence of lecithotrophic (= nonfeeding) larvae in molluscs and hyoliths (Nützel et al. 2006). Unfortunately, protoconchs are broken off in all accessible specimens of both Circotheca smetanai and Probactrotheca briketa. According to the interpretation of hyolithids by Marek \& Yochelson (1976) and Marek et al. (1997), adult specimens of $P$. briketa and $C$. smetanai were suspension feeders living most probably on and/or partly embedded in muddy substrates in relatively shallow water settings.

\section{Acknowledgements}

The authors are indebted to Pavel Štys (Charles University in Prague) for consultation on nomenclatorial rules. This study was supported by MSM 0021620855, the Czech Science Foundation through the Project No. 205/09/1521 (Feeding strategies in Cambrian to Middle Ordovician of the Barrandian Region) and by project of Ministry of Culture CR No. DE06P04OMG009. This contribution benefited from the constructive suggestions made by John S. Peel (Uppsala University, Uppsala, Sweden) and Jan Bergström (Swedish Museum of Natural History, Stockholm, Sweden).

\section{References}

Álvaro, J.J., Vizcaïno, D., Kordule, V., Fatka, O. \& Pillola, G.L. 2004. Some solenopleurine trilobites from the Languedocian (Late Mid Cambrian) of Western Europe. Geobios 37, 135-147. DOI 10.10116/j.geobios.2003.03.009

Barrande, J. 1867. Systême Silurien du centre de la Bohême. Vol. 3. 179 pp. Prague \& Paris.

Berg-Madsen, V. \& Malinky, J.M. 1999. A revision of Holm's Mid and Late Cambrian hyoliths of Sweden. Palaentology 42(5), 841-885. DOI 10.1111/1475-4983.00099

DzıK, J. 1978. Larval development of hyolithids. Lethaia 11, 293-299. DOI 10.1111/j.1502-3931.1978.tb01884.x

FATKA, O. 1990. Das Kambrium von Skryje und Týřovice, 12-17. In Weidert, K.H. (ed.) Klassische Fundstellen der Paläontologie, Band 2. Goldschneck, Korb.

FatKa, O., Kordule, V. \& Szabad, M. 2004. Stratigraphical distribution of Cambrian fossils in the Príbram-Jince Basin (Barrandian area, Czech Republic). Senckenbergiana lethaea 84(1/2), 369-384. DOI 10.1007/BF03043477
FatKa, O., Kraft, P. \& Szabad, M. in press. A first report of Sphenothallus Hall, 1847 in Cambrian of Europe. Comptes Rendus Palevol 11.

FAtKa, O., Micka, V., SZABad, M., VoKÁČ, V. \& Vorel, T. 2011. Nomenclature of Cambrian lithostratigraphy of the SkryjeTýřovice Basin. Bulletin of Geosciences 86(4), 841-858. DOI 10.3140/bull.geosci.1284

FISHER, D.W. 1962. Small conoidal shells of uncertain affinities, 98-143. In MOORE, R.C. (ed.) Treatise on invertebrate paleontology, part W. University of Kansas Press \& Geological Society of America.

Geyer, G. \& Shergold, J.H. 2000. The quest for internationally recognized divisions of Cambrian time. Episodes 23, 188-195.

Hall, J. 1847. Paleontology of New York. Volume I. Containing descriptions of the organic remains of the Lower Division of the New York system (equivalent to the Lower Silurian rocks of Europe). 338 pp. C. Van Benthuysen, Albany.

Holm, G. 1893. Sveriges Kambrisk-Silurska Hyolithidæ och Conularidæ. Sveriges Geologiska Undersökning, Afhandlingar och uppsatser, Ser. C 112, 1-172.

Maletz, J., Steiner, M. \& FatKa, O. 2005. 'Middle' Cambrian pterobranchs and the Question: What is a graptolite. Lethaia 38(1), 73-85. DOI 10.1080/00241160510013204

MaLInKy, J.M. 1987. Taxonomic revision of lower and middle Paleozoic Orthothecida (Hyolitha) from North America and China. Journal of Paleontology 61(5), 942-959.

Malinky, J.M. 2002. A revision of Early to Mid Ordovician hyoliths from Sweden. Palaeontology 45(3), 511-555.

DOI 10.1111/1475-4983.00248

MaLinKY, J.M. 2009. First occurrence of Orthotheca Novák, 1891 (Hyolitha, Early Devonian) in North America. Journal of Paleontology 83(4), 588-596. DOI 10.1666/08-164R.1

Malinky, J. M., Eriksson, M.E. \& Ahlberg, P. 2009. 'Mediterranean Province' hyoliths from the middle Cambrian and Upper Ordovician of Sweden. GFF 131(4), 281-291.

DOI 10.1080/11035890903458693

MAReK, L. 1963. New knowledge on the morphology of Hyolithes. Sborník geologických věd, Paleontologie 1, 53-73.

MAREK, L. 1966. New hyolithid genera from the Ordovician of Bohemia. Časopis Národního muzea, Oddíl prírodovědný 135(2), 89-92.

Marek, L. 1972. Middle Cambrian hyolithes Maxilites gen. nov. [Maxilites gen. nov. ze středního kambria (Hyolitha)]. Časopis Národního muzea, Oddíl přirodovědný 141(1-2), 69-72.

MAREK, L. 1975. Objev nové hyolithové fauny ve skryjsko-týřovickém kambriu (The discovery of a new hyolithid fauna in the Skryje-Týřovice Cambrian). Bohemia centralis 4, 64-71.

MAREK, L. 1976. The distribution of the Mediterranean Ordovician Hyolitha, 491-499. In BASSETT, M.G. (ed.) The Ordovician System: Proceedings of a Palaeontological Association Symposium. University of Wales Press and National Museum of Wales, Cardiff.

MAREK, L. 1980. Slapylites gen. nov. z českého středního kambria Hyolitha. Časopis Národního muzea, Oddíl př́rodovědný 149(3), 156-160.

Marek, L. 1981. Middle Cambrian Hyolithid family Parentilitidae fam. nov. (Parentilitidae fam. nov., nová čeled' hyolitů 
ze středního kambria). Časopis Národního muzea, Oddíl př́rodovědný 150(3), 163-168.

MAREK, L. 1983a. Hyoliti českého středního kambria (Hyoliths of the Bohemian Middle Cambrian). Unpublished manuscript, Ústav geologie a geotechniky Československé akademie věd, Prague.

MAREK, L. 1983b. The hyoliths in the Arenigian of Montagne Noire. Mémoire de la Société d'Etudes Scientifiques de l'Aude, 57-62.

Marek, L., Parsley, R.L. \& Galle, A. 1997. Functional morphology of hyoliths based on flume studies. Věstník Českého geologického ústavu 72(4), 277-283.

MareK, L. \& Yochelson, E.L. 1976. Aspect of the biology of Hyolitha Mollusca. Lethaia 9, 65-82. DOI 10.1111/j.1502-3931.1976.tb00952.x

Martí Mus, M. \& BergströM, J. 2005. The morphology of hyolithids and its functional implications. Palaeontology 48(6), 1139-1167. DOI 10.1111/j.1475-4983.2005.00511.x

Mašek, J., Straka, J., Hrazdíra, P., Pálenský, P., Štěránek, P. \& HỦla, P. 1997. Geological and nature conservation map. Protected landscape area and biosphere reserve Krivoklátsko. Czech Geological Survey, Prague.

Mergl, M. \& Kordule, V. 2008. New Middle Cambrian lingulate brachiopods from the Skryje-Týřovice area (Central Bohemia, Czech Republic). Bulletin of Geosciences 83(1), 11-22. DOI 10.3140/bull.geosci.2008.01.011

Missarzhevskiy, V.V. 1969. Descriptions of hyolithids, gastropods, hyolithelminths, camenids and forms of an obscure systematic position, 105-175. In Rozanov, A.Y., MissarzheVSkiy, V.V., Volkova, L.G., Krylov, I.N., Keller, B.M., Korolyuk, I.K., Lendzion, K., MikhnyaK, R., Pykhova, N.G. \& Sidorov, A.A. Tommotsky jarus i problema nizhnej granitzy Kembriya. Trudy Ordena Trudvogo krasnogo znameni Geologicheskogo instituta 206.

NovÁk, O. 1886. Zur Kenntnis der Fauna der Etage F-Fl in der paläozoischen Schichtengruppe Böhmens. Aus den Sitzungsberichten der königlichen Böhmens Gesellschaft der Wissenschaften, 1-27.

NovÁK, O. 1891. Revision der paläozoischen Hyolithiden Böhmens. Abhandlungen Böhmischen Gesellschaft Wissenschaften 7(4), 1-48.

NütZel, A., Lehnert, O. \& FrÝda, J. 2006. Origin of planktotrophy - evidence from early molluscs. Evolution \& Development 8(4), 325-330.

DOI $10.1111 / \mathrm{j} .1525-142 \mathrm{X} .2006 .00105 . \mathrm{x}$

PeEL, J.S. 2010. Articulated hyoliths and other fossils from the Sirius Passet Lagerstätte (early Cambrian) of North Greenland. Bulletin of Geosciences 85(3), 385-394.

DOI 10.3140/bull.geosci.1207
Peel, J.S. \& Ineson, J.R. 2011. The extent of the Sirius Passet Lagerstätte (early Cambrian) of North Greenland. Bulletin of Geosciences 86(3), 535-543.

DOI 10.3140/bull.geosci.1269

Sysoev, A.V. 1957. K morfologii, sistematicheskomu polozheniu i sistematike chiolotov (To the morphology, systematic position and systematics of hyoliths). Doklady Akademii nauk SSSR 116(2), 304-307.

Sysoev, A.V. 1958. The superorder Hyolithoidea, 184-190. In Orlov, Y.A., Luppov, N.P. \& Drushits, V.V. (eds) Principles of Palaeontology. Mollusca, Cephalopoda 6. 359 pp. Gosgeotekhizdat, Moscow.

Sysoev, A.V. 1968. Stratigrafyia i khiolity drevnejshikh sloev nizhnego kembryia Sibirskoj platformy [Stratigraphy and hyoliths of the oldest Lower Cambrian beds of the Siberian Platform]. Akademiya Nauk SSSR. 67 pp. Yakutskiy filial Sibirskogo otdeleniya Instituta Geologii, Yakutsk. [in Russian]

VALENT, M. 2004. Hyoliti středního kambria skryjsko-týřovické oblasti (Middle Cambrian hyoliths of the Skryje-Týrovice area). 88 pp. Mgr. dissertation, MS Charles University, Prague. [in Czech]

VALENT, M. 2006. Stratigraphic distribution of the class Hyolitha (Mollusca) in the Barrandian area (Czech Republic). Acta Universitatis Carolinae, Geologica 47(1-4), 183-188.

Valent, M., Fatka, O. \& Marek, L. in press. Gracilitheca and Nephrotheca in Cambrian of the Barrandian area (Hyolitha, Orthothecida, Czech Republic). Alcheringa.

Valent, M., FatKa, O., Micka, V. \& Szabad, M. 2009. Jincelites vogeli gen. et sp. nov. (Hyolitha) from the Cambrian of Czech Republic (Příbram-Jince Basin, Teplá-Barrandian region). Bulletin of Geosciences 84(1), 179-184.

DOI 10.3140/bull.geosci.1084

Valent, M., Fatka, O., Szabad, M., Micka, V. \& Marek, L. 2011a. Skryjelites auritus gen. et sp. nov. and Quasimolites quasimodo gen. et sp. nov. - two new hyolithids (?Mollusca) from the Middle Cambrian of Czech Republic. Zootaxa.

Valent, M., FatKa, O., Szabad, M. \& Vokáč, V. 2011 b. Carinolithidae fam. nov., Carinolithes bohemicus sp. nov. and Slehoferites slehoferi gen. et sp. nov. - new hyolithid taxa from the Bohemian Middle Cambrian (Skryje-Týřovice Basin, Czech Republic). Palaeobiodiversity and Palaeoenvironments 91(2), 101-109. DOI 10.1007/s12549-011-0049-1

WalcotT, C.D. 1911. Cambrian geology and paleontology II, no. 5 - Middle Cambrian annelids. Smithsonian Miscellaneous Collections 57(5), 109-144. 